\title{
HR BUSINESS PARTNER - THE RANGE OF ROLES AND SERVICES
}

\author{
EWA MATUSKA, ${ }^{1}$ PIOTR NIEDZIELSKI ${ }^{2}$ \\ ${ }^{1}$ Pomeranian University, Faculty of Management and Safety Sciences, POLAND \\ e-mail: ewa.matuska@apsl.edu.pl \\ ${ }^{2}$ University of Szczecin, Faculty of Management and Economics of Services, POLAND \\ e-mail: piotr.niedzielski@wzieu.pl
}

RECEIVED
ACCEPTED
JEL
CLASSIFICATION

KEYWORDS

ABSTRACT
6 November 2018

3 December 2018

J24, L84, M12, 015

business partnering, hr roles and services, HRBP theoretical models

The aim of the article is to present the possible roles and services which can be gained by organizations from the business offer performed by hr business partners. The history of the HRPB development concept is shortly described as well as their round of evolution during last two decades. The main theoretical models of HRBP and their implication for their possible range of hr and business services are discussed. In conclusion is stressed the need of widening HRBP services for the other categories of customers, including small companies and individual subjects.

\section{Introduction}

The current, challenging changes in the organizations' environment, including mismatches between work supply and demand, changes in work career models, digitalization of business processes, etc. hardly press executive managers to seek for the new solutions promising optimization of their overall business processes and organizational structures. One of the most effective forms of the assistance on this way offer the concept 
of business partnering which can be dedicated to the complex or selected enterprise's functions (Robinson, Robinson, 2005, p. 16). In Poland, together with the transformation from the so - called "employer's labour market" into the "employee's labour market", caused mainly by the significant drop of the unemployment level during last few years (Unemployment rate..., 2018), we can assume the visible progress in appreciation of the role of human capital in building the enterprise's value. At the same time, being ready to invest in human resources, organizations all over the world strive to improve their hr processes and cost effectiveness (Charan, 2014, pp. 33-34).

The service aimed to optimize systems and tools responsible for managing human resources within organizations perform external specialists - hr business partners (HRBPs). This function, described as "the shared model of hr services", was introduced by Dave Ulrich in his Human Resource Champions book (Ulrich, 1997). During last two decades the primary Ulrich's approach to the general role of HRBP has passed many changes and ongoing research have discovered the new fields of possible HRBP expertise together with observed changes of performing business models.

Today, although multiple industry researches indicate that HR capabilities of enterprises systematically improve, still many companies are not use at all the offer of HRBP's services or use them only fragmentary. The most recognized HRBP organizations, including big global consultancies like EY and similar, offer their services mostly to big companies which can pay for the wide and complex hr service. For the majority of medium and small companies HRPB offer stays mostly unknown because seems to be simply not necessary. It suggests the service delivered by HRBPs is not tailored with different kinds of market needs defined by companies and also by individual subjects. To try find the reason of this situation first needs explanation what exactly HRPB can offer.

\section{What is hr business partner?}

Generally can be said hr business partner (HRBP) is an outsourcing service of B2B and B2C type delivered by the subject (an individual or company) who helps organization reach their strategic goals in area of human resources management and implement long-term workplace success strategies (McCracken, Mclvor, 2013, p. 1685-1707). The potential secondary kind of customers for the HRPB are individual subjects, looking for personal hr consultancy, mainly job seekers (Piwowar-Sulej, 2017, pp. 77-90). The key proposal of any HRBP model is the centralization of $\mathrm{hr}$ administrative functions and creation of specialist centres of excellence (COEs) to assist companies with implementation of the true strategic human resources management. By this way have been established the new type of hr professionals - the hr business partners (experts), whose the main task is to embed themselves within a business unit and provide high level strategic consultations, both on hr field of expertise as well as on a whole business area.

\section{HRBP roles as hr service performer}

The most simple classification of HRBP services is into two categories:
a) an internal services - performed directly and within the organization and tailoring their hr structure and functions (as the complex or facultative offer);
b) an external services - delivered to different individual subjects, largely for job seekers (Piwowar-Sulej, 2017, p. 78).
In the literature we can find different classifications of the roles of hr departments (see more: Ulrich, Brockbank, 2005 , pp. 206-226). The attention is drawn to the fact of overall shift from the strictly administrative supportive role 
of hr functions towards delivering strategic management support through improvement hr processes (Lo, Macky, Pio, 2015, pp. 2308-2328).

Dave Ulrich's initial (1997) framework of HRBP's roles includes three strategic partners roles as: Change Agent, Employee Champion, and Functional Expert. Then, in the "HR Value Proposition" (Ulrich, Brockbank, 2005) this model was redefined into five specific roles (as so called five-character model) where the roles of Leader and Human Capital Developer had been added. This model integrates the change agents function into the strategic partners position. The last proposal of the Ulrich and his team represents "2016 HR competency Model" (Ulrich et al., 2015) which well describes current variable fields of HRPB potential service activities (see Figure 1).

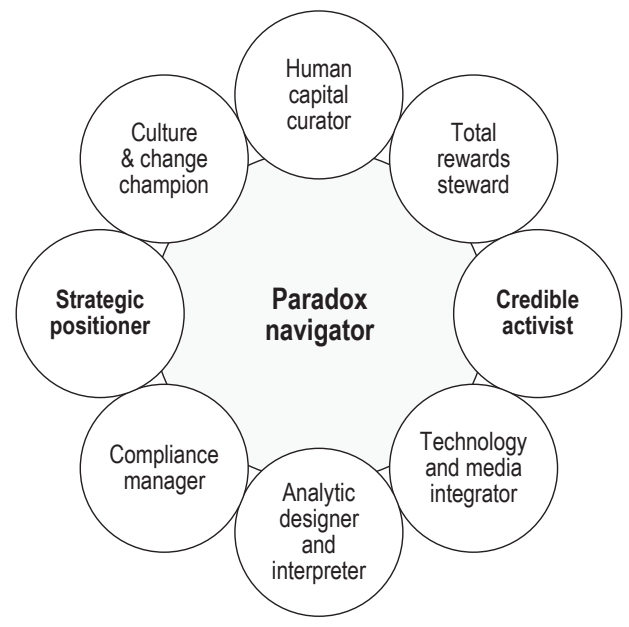

Figure 1. Fields of HRBP roles

Source: Ulrich et al. (2015).

The model enumerates eight roles, or domains of expertise, which are the roles of HRBP as:

- a strategic positioner,

- a credible activist,

- a human capital curator,

- an analytic designer and interpreter,

- a culture and change champion,

- a technology and media navigator,

- a total rewards steward,

- a compliance manager and

- a paradox navigator.

The specific content of all these HRBP's roles/domains of expertise together with description of their main tasks in each domain presents Table 1. 
Table 1. HRBP domains and tasks

\begin{tabular}{ll}
\hline \multicolumn{1}{c}{ Domain } & \multicolumn{1}{c}{ Description of HRBP's tasks } \\
\hline Strategic Positioner & $\begin{array}{l}\text { The extent to which the hr professional can evaluate both the external and internal business contexts and } \\
\text { translate those evaluations into practical insights that help position the organization to be successful. }\end{array}$ \\
Credible Activist & $\begin{array}{l}\text { The extent to which hr professionals achieve the trust and respect they need within the organization to be viewed } \\
\text { as valued and valuable partners. }\end{array}$ \\
Culture and Change Champion & $\begin{array}{l}\text { By managing both change and culture hr professionals help make things consistently happen within the } \\
\text { organization. }\end{array}$ \\
Human Capital Curator & $\begin{array}{l}\text { Offering integrated and innovative hr solutions for managing people within their organization ensure human } \\
\text { capital development within organization. }\end{array}$ \\
Total Rewards Steward & $\begin{array}{l}\text { Creating total reward systems which include compensation and benefits (financial rewards) as well as meaning } \\
\text { from work (nonfinancial rewards). }\end{array}$ \\
Technology and Media Integrator & $\begin{array}{l}\text { Leveraging technology and technological tools to support their efforts to create high performing organizations. } \\
\text { They also rely on social media to recruit, retain, develop and engage human capital. }\end{array}$ \\
Analytics Designer and Interpreter & $\begin{array}{l}\text { Hr Professionals must be able to use analytics to impact decision making. Analytics goes beyond collecting data } \\
\text { and having scorecards to using data to improve business decisions. }\end{array}$ \\
Compliance Manager & $\begin{array}{l}\text { Hr Professionals must be able to manage the processes related to compliance by following regulatory guidelines. } \\
\text { The compliance function varies by geography. }\end{array}$ \\
Paradox Navigator & $\begin{array}{l}\text { Hr professionals are increasingly asked to maximize ideas and outcomes that may be inherently in opposition } \\
\text { with each other. These professionals must constantly manage the paradoxes or tensions that exist in work } \\
\text { settings. }\end{array}$ \\
\hline
\end{tabular}

Source: Ulrich et al. (2015).

However, as the potential target group for HRBP services is systematically widening and deepening, thus also the theoretical concept of the hr partnering is during conceptualization. What is the common for this attempts is the switch of HRBP position from the administrative/supportive functions to the strategic/ change management ones and the ambition delivering tailored services to match interest of employer, other stakeholders and employees.

\section{The evolution of HRBP poles and potential services}

Following the changes of HRBP theoretical model of services during last two decades we can use the concept of HRPB "Seven Rounds" developed by the research of RBL Group (Ulrich et al., 2015) demonstrated during Human Resource Competency Conference at University of Michigan. This approach is illustrated in a Table 2.

The early theoretical models of HRBP (Round 1-2-3 in a Table 2) referred to the goal, area of action and responsibility of the hr function as a business partner. There were created models of competence of departments and $\mathrm{hr}$ specialists to meet the challenges arising from individual roles. This intermediate period (Rounds 4-5-6) illustrates the transformation of HRPB role from administrative/supportive to business/supportive - from then function of the change agent into the strategic partner position. The latest art of the model (Round 7) represents complex nine - character model described as a current 2016 HR competency Model (Ulrich et al., 2015). This model can be also used as comprehensive model of HRBP professional job description and the frame work for the definition of the possible HRPB services. 
Table 2. The Seven Rounds of the HRBP Research

\begin{tabular}{|c|c|c|c|c|c|c|c|}
\hline $\begin{array}{c}\text { Area } \\
\text { of expertise }\end{array}$ & Round 11987 & Round 21992 & Round 31997 & Round 42002 & Round 52007 & Round 62012 & Round 72016 \\
\hline \multirow{2}{*}{ Business } & \multirow{2}{*}{$\begin{array}{l}\text { Business } \\
\text { Knowledge }\end{array}$} & \multirow{2}{*}{$\begin{array}{l}\text { Business } \\
\text { Knowledge }\end{array}$} & \multirow{2}{*}{$\begin{array}{l}\text { Business } \\
\text { Knowledge }\end{array}$} & $\begin{array}{l}\text { Business } \\
\text { Knowledge }\end{array}$ & Business Ally & \multirow{2}{*}{$\begin{array}{l}\text { Strategic } \\
\text { Positioner }\end{array}$} & \multirow{2}{*}{$\begin{array}{l}\text { Strategic } \\
\text { Positioner }\end{array}$} \\
\hline & & & & $\begin{array}{c}\text { Strategic } \\
\text { Contribution }\end{array}$ & $\begin{array}{l}\text { Strategic } \\
\text { Architect }\end{array}$ & & \\
\hline \multirow{6}{*}{$\begin{array}{c}\text { Human } \\
\text { Resources (HR) }\end{array}$} & \multirow{6}{*}{ Hr Delivery } & \multirow{6}{*}{ Hr Delivery } & \multirow{6}{*}{ Hr Delivery } & \multirow{3}{*}{ Hr Delivery } & \multirow{3}{*}{ Hr Delivery } & \multirow{3}{*}{ Hr Delivery } & $\begin{array}{c}\text { Human Capital } \\
\text { Curator }\end{array}$ \\
\hline & & & & & & & $\begin{array}{l}\text { Total Rewards } \\
\text { Steward }\end{array}$ \\
\hline & & & & & & & $\begin{array}{c}\text { Analytics } \\
\text { Designer and } \\
\text { Interpreter }\end{array}$ \\
\hline & & & & \multirow{3}{*}{ Hr Technology } & \multirow{3}{*}{ Hr Technology } & \multirow{3}{*}{ Hr Technology } & $\begin{array}{c}\text { Compliance } \\
\text { Manager }\end{array}$ \\
\hline & & & & & & & $\begin{array}{l}\text { Technology } \\
\text { \& Media } \\
\text { Integrator }\end{array}$ \\
\hline & & & & & & & $\begin{array}{l}\text { Paradox } \\
\text { Navigator }\end{array}$ \\
\hline Change & Change & Change & Change & \multirow{2}{*}{$\begin{array}{l}\text { Strategic } \\
\text { Contribution }\end{array}$} & \multirow{2}{*}{$\begin{array}{c}\text { Culture and } \\
\text { Change Steward }\end{array}$} & $\begin{array}{c}\text { Change } \\
\text { Champion }\end{array}$ & \multirow{2}{*}{$\begin{array}{l}\text { Culture and } \\
\text { Change } \\
\text { Champion }\end{array}$} \\
\hline Culture & & & Culture & & & $\begin{array}{l}\text { Capability } \\
\text { Builder }\end{array}$ & \\
\hline Personal & & $\begin{array}{l}\text { Personal } \\
\text { Credibility }\end{array}$ & $\begin{array}{l}\text { Personal } \\
\text { Credibility }\end{array}$ & $\begin{array}{l}\text { Personal } \\
\text { Credibility }\end{array}$ & Credible Activist & Credible Activist & $\begin{array}{l}\text { Credible } \\
\text { Activist }\end{array}$ \\
\hline
\end{tabular}

Source: Ulrich et al. (2015).

\section{HRBP in Poland}

On the Polish market, oppositely to the situation in west Europe or US, HRBP ideas are still not yet so popular and its roles are not clear (Piwowar-Sulej, 2017; Popieluch, 2018). However, both the researchers of HR processes in organizations and practitioners try to determine the key aspects of the role and competences necessary for this position. Such attempts represents the proposal of Karina Popieluch (2018) who enumerates the following list of HRPB roles:

- adjusting HR strategy to the changing needs of the organization and its environment,

- developing the next generation of leaders,

- identification of critical HR indicators,

- identification of new business strategies,

- identifying talent-related problems before they touch the company,

- prioritization of HR needs,

- redesigning structures supporting the implementation of strategic goals,

- understanding the business needs of talents.

All these roles represent not only strategic hr issues but also the strategic business roles.

On our domestic background have appeared recently also first attempts for the conceptualization HRBP model and specification its characteristics (Filipowicz, 2016). 
Using a graphical house metaphor (see Figure 2) based on strong pillars (analogous to Toyota's "house" model), the author, as the main goal of the HR BP (house's roof) function does not focus on achieving specific business results (short-term perspective), but firstly - on building a highly-effective organization (approach long-term). The floors of the house are made up of: providing the best employees, efficiency management, and organization development. The wall pillars are: development in the role of HR Business Partner and business partnership.

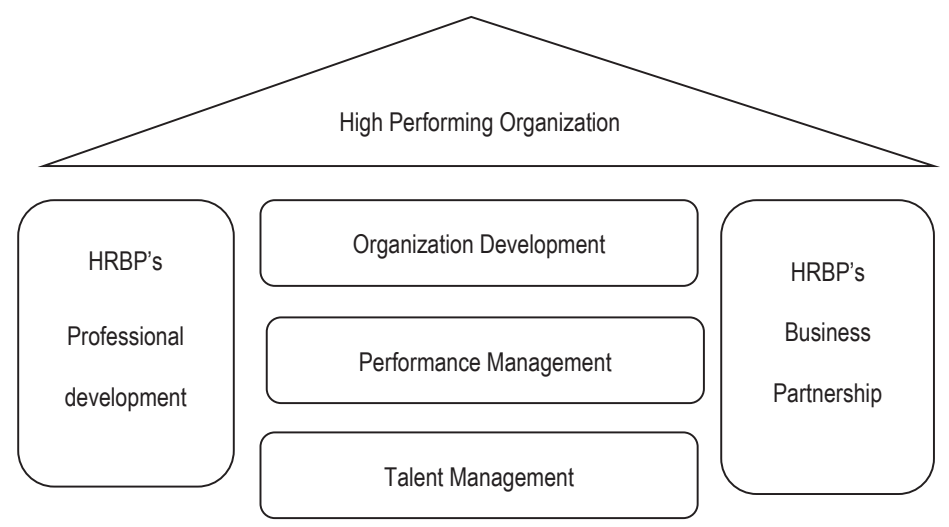

Figure 2. HRBP model of Grzegorz Filipowicz

Source: Filipowicz (2017), p. 8.

Above description of HRBP model seems to be well harmonized with the 2016 HR competency Model formed by Ulchich et al. in 2016 as they both aims to cover with HRPB activities complex organizational strategic management goals. Both models create not only the framework for a useful theory of hr management, but first - can serve organizations as a reference point for the revision of their hr practices and planning how to improve them and by this way - how to reach better business efficiency.

\section{Conclusions}

During last two decades the task hr processes optimization has been increasingly entrusted to care of the external experts hr business partners (HRBPs) and the spectrum of their roles and service have passed the evolution from supportive (administration) function - to developmental and strategic management function. Polish organizations, especially from the sector of small enterprises are still mostly unaware the proposition value of possible services of HRPB and how they could improve their market competitive position. However, together with dissemination of digitalization business processes, including hr issues, the use of the range of services of HRBP should be prospective. The newest theoretical HRPB models can be an inspiration for companies how to improve not only their management processes in the hr sphere, but also - the overall business efficiency. However, the HRPB subject have to consider how to encourage also customers from outside of big companies category to use their services. It demands also for re-definition of HRBP's business goals. 


\section{References}

Charan, R. (2014). It's Time to Split HR. Harvard Business Review, 92, 33-34.

Filipowicz, G. (2016). HR Business Partner. Koncepcja i praktyka. Warszawa: Wolters Kluwer.

Filipowicz, G. (2017). HR Business Partner - od modelu do powszechnej praktyki. In: G. Filipowicz (ed.), HR Business Partner. Praktyczne rozwiązania budowania wysokoefektywnych organizacji (pp. 6-10). Warszawa: Infor PL.

Lo, K., Macky, K., Pio, E. (2015). The HR Competency Requirements for Strategic and Functional HR Practitioners. The International Journal of Human Resource Management, 26 (18), 2308-2328. Retrieved from: http://dx.doi.org/10.1080/09585192.2015.1021 82.

McCracken, M., Mclvor, R. (2013). Transforming the HR Function through Outsourced Shared Services: Insights from the Public Sector. The International Journal of Human Resource Management, 24, 1685-1707. Retrieved from: http://dx.doi.org/10.1080/0958519 2.2012.725070.

Piwowar-Sulej, K. (2017). The concept of HR business partner in a project oriented organization. Central European Review of Economics and management, 1 (2), 77-90. Retrieved from: www.cerem-review.eu www.ojs.wsb.wroclaw.

Popieluch, K. (2018). HR Business Partner. Rola - funkcje - perspektywy. Warszawa: Wydawnictwo Naukowe PWN.

Robinson, D.G., Robinson, J. (2005). Strategic Business Partner: Aligning People Strategies with Business Goals. San Francisco: Berrett-Koehler Publishers.

Ulrich, D. (1997). Human resource champions: the next agenda for adding value and delivering results. Boston: Harvard Business School Press.

Ulrich, D., Brockbank, W. (2005). The HR Value Proposition. Boston: Harvard Business School Press.

Ulrich, M., Kryscynski, D., Ulrich, D., Brockbank, W., Slade, J. (2015). 2016 HR competency Model. RBL Group presentation, Human Resource Competency Conference 2016, University of Michigan's Ross School of Business, slide 20. Retrieved from: http:// www.apg.pt/downloads/file954_pt.pdf.

Unemployment rate 1990-2018 (2018). Statistic Poland. Retrieved from: https://stat.gov.pl/en/topics/labour-market/registeredunemployment/unemployment-rate-1990-2018,3,1.html.

Cite this anticle aS: Matuska, E., Niedzielski, P. (2018). Hr business partner - the range of roles and services. European Journal of Service Management, 4 (28/1), 191-197. DOI: 10.18276/ejsm.2018.28/1-24. 